\title{
Application of Membrane Technology towards The Reusability of Lake Water, Mine Water, and Tube Well Water
}

\author{
(Penggunaan Teknologi Membran untuk Rawatan dan Penggunaan Semula Air Tasik, Air Tasik Lombong, \\ dan Air Perigi) \\ Y.H. Teow*, M.S.H. Ghani, W.N.A. Wan Mohammad Hamdan, N.A. Rosnan, N.I. Mohamad Mazuki \& K.C. Ho \\ Faculty of Engineering \& Built Environment, Universiti Kebangsaan Malaysia, Malaysia
}

\begin{abstract}
Severe water shortage caused by El-Nino has caused life-threatening drought conditions globally. This natural disaster has put millions of lives at risk and forcing the people to search for waster. However, the water scarcity problem was not just limited to the countries that were strike by El-Nino. Poor water management and climate change were bringing droughts to Asia and the Pacific. The water scarcity worldwide has recently reached the alarming rate and received the greatest attention among the people. Membrane technology is an innovative technology which has proven to be effective and efficient for water and wastewater treatment. Therefore, membrane technology has high potential to be employed for the treatment of lake water, mine water, and tube well water in increasing the fresh water production for reuse purpose. The objective of this work is to investigate the potential of membrane technology for treating the lake water, mine water, and tube well water. A laboratory bench-scale dead-end test rig was used in this study to evaluate the performance of commercial flatsheet nanofiltration (NF) - NF270 and reverse osmosis (RO) - BW30 membranes. Both source water and treated water were analysed based on chemical oxygen demand (COD), ammonia nitrogen $\left(\mathrm{NH}_{3}-\mathrm{N}\right)$, colour, total suspended solid (TSS), pH, and temperature. In order to prove the reuse concept of membrane technology, the permeate water quality after the membrane filtration process was compared with National Water Quality Standard (NWQS) of Malaysia. The results from this study shown that the permeate water filtered by NF270 and BW30 membranes were able to meet the NWQS Class III, which was suitable to recycled for livestock drinking and irrigation purposes.
\end{abstract}

Keywords: Lake water; Mine water; Tube well water; Membrane technology; Water reuse

\section{INTRODUCTION}

In recent decades, the general population of the world has been subjected to a number of environmental issues such as global warming, natural disasters, pollution, etc which were mainly triggered by the human activities (Zaiedy et al., 2016). Among these issues, a global water crisis known as "water scarcity" is now gaining the most attention. Water scarcity is a wide definition of water-related issues such as water stress, water shortage, and a prevailing water crisis (EEA 2012). Catastrophic water shortage caused by El-Nino, a periodic weather event characterized by warm ocean temperature has driven to life-threatening drought conditions globally in Central and South America, Southern and Eastern Africa, and the Pacific islands (World Vision 2016). This natural disaster was putting millions of lives at risk and forcing the people to search for the water source. However, the water scarcity problem was not just limited to the strike of El-Nino. There were similar situations in countries throughout Asia and the Pacific. Droughts and water scarcity have been experienced throughout the region due to in part to seasonal dry periods by the climate change and poor water management.

Despite the world being covered by more than $70 \%$ of water, only $2 \%$ of it is fresh and drinkable with only $1 \%$ is easily accessible. According to United Nations, as of December 2013, 783 million people do not have access to clean and safe water. This is an alarming rate and is not an ideal amount of water to supply to global demand of 6.8 billion people (Hodgson 2016). Water scarcity affects almost all aspect of day-to-day life from regular consumption, agriculture, education, and in some worse cases it is even the cause of death. However, not only day-to-day life water disrupted, but the local economy also felt the strike by the lack of clean water. At larger perspective, 6 to 8 million people die annually worldwide is due to water-related disease (UN Water Organization 2013; The Water Project Organization 2014). The negative health-related factors due to water scarcity include (although not limited to) dehydration, exposure to pathogenic microbes, diarrhoea schistosomiasis, trachoma, and intestinal helminths (Tarrass \& Benjelloun 2012).

Many countries in Asia and the Pacific have come up with strategies and solution to address the worsening droughts they are facing. In Cambodia, Viet Nam, and Lao People's Democratic Republic, irrigation systems were improved and early warning systems were set up. In the People's Republic of China, improved water management and policies and disaster preparedness programs were put into place. In Sri Lanka, water was moved from Mahaweli river basin to areas where scare water supplies undermine agricultural output and household incomes. Whereas, in Uzbekistan, agricultural practices were improved and water was shared regionally in order to address scarcity and droughts (Asian Development 
Bank 2017). However, these strategies are not sufficient to tackle the global water scarcity issue. People had realised that extraordinary actions are required such as reclamation and reuse of water and wastewater.

Recently, membrane technology is a characteristic separation process which has become more and more popular in water industry to replace the conventional water treatment process in increasing fresh water production for various domestic and industrial purposes. The advantages of membrane technology including small operational area, high filtration efficiency, direct operational handling, and without chemical addition which can avoid the formation of toxic disinfection by-products (Rana et al. 2005). Attributed to these advantages, membrane technology is gaining high attention from many researchers. With the current worldwide critical water shortage, this study is aim to cope this problem by looking into the potential of membrane technology to be implemented for the creation of process water from lake water, mine water, and tube well water for potable use. Since membrane technology has been widely applied in treating various types of water and wastewater, it has great potential to be utilized for lake water, tube well water, and tube water reuse programme.

\section{MATERIAL AND METHODOLOGY}

MATERIALS

Two different types of commercial flat-sheet nanofiltration (NF) membrane, NF270 and reverse osmosis (RO) membrane, BW30 purchased from Dow Filmtec, USA were used in this study. The specifications of the used commercial flat-sheet membranes are illustrated in Table 1.

TABLE 1. Properties of the used commercial flat-sheet membranes, NF270 and BW30

\begin{tabular}{|c|c|c|c|c|c|c|}
\hline Membrane & Material & $\begin{array}{l}\text { MWCO } \\
(\mathrm{Da})^{\mathrm{a}}\end{array}$ & $\begin{array}{l}\text { Stabilized Salt } \\
\text { Rejection }(\%)\end{array}$ & $\begin{array}{c}\text { Maximum Operating } \\
\text { Pressure (bar) }\end{array}$ & $\mathrm{pH}$ Range & $\begin{array}{c}\text { Maximum Operating } \\
\text { Temperature }\end{array}$ \\
\hline NF270 & Polyamide & $200-400$ & $>97.0$ & 41 & $2-11$ & $45^{\circ} \mathrm{C}$ \\
\hline BW30 & Polyamide & $\sim 100$ & 99.5 & 41 & $2-11$ & $45^{\circ} \mathrm{C}$ \\
\hline
\end{tabular}

${ }^{a}$ Information obtained from the manufacturer

\section{SAMPLE COLLECTION POINTS}

Lake water (Sample 1) used in this study was collected from Tasik Putrajaya located at Putrajaya, Malaysia with GPS coordinate of $2.895865^{\circ}, 101.681393^{\circ}$. The satellite map for Tasik Putrajaya was shown in Figure 1. The lake has an area of $7.5 \mathrm{~km}^{2}$ with a storage capacity of 45 million $\mathrm{m}^{3}$. Whereas, the mine water (Sample 2) used in this study was collected from Tasik Mines located at Seri Kembangan,
Malaysia with GPS coordinate of $3.030390^{\circ}, 101.712363^{\circ}$. The satellite map for Tasik Mines was shown in Figure 2. The lake has an area of $0.6 \mathrm{~km}^{2}$. On the other hand, the tube well water (Sample 3) used in this study was collected from the tube well located at Kolej Keris Mas, Universiti Kebangsaan Malaysia, Bangi, Malaysia with GPS coordinate of $2.926981^{\circ}$, $101.788484^{\circ}$. The satellite map for Kolej Keris Mas was shown in Figure 3.

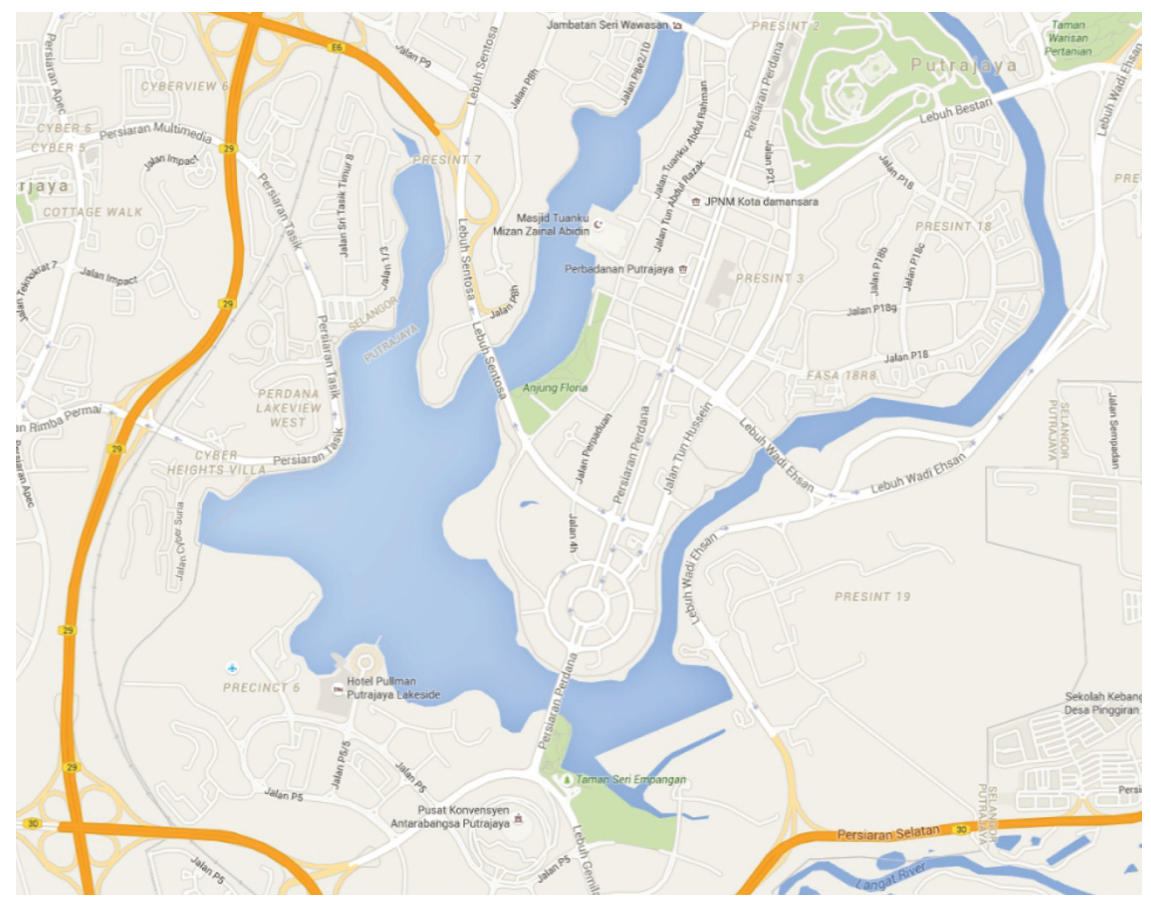

FIGURE 1. Satellite map for Tasik Putrajaya, Putrajaya, Malaysia 


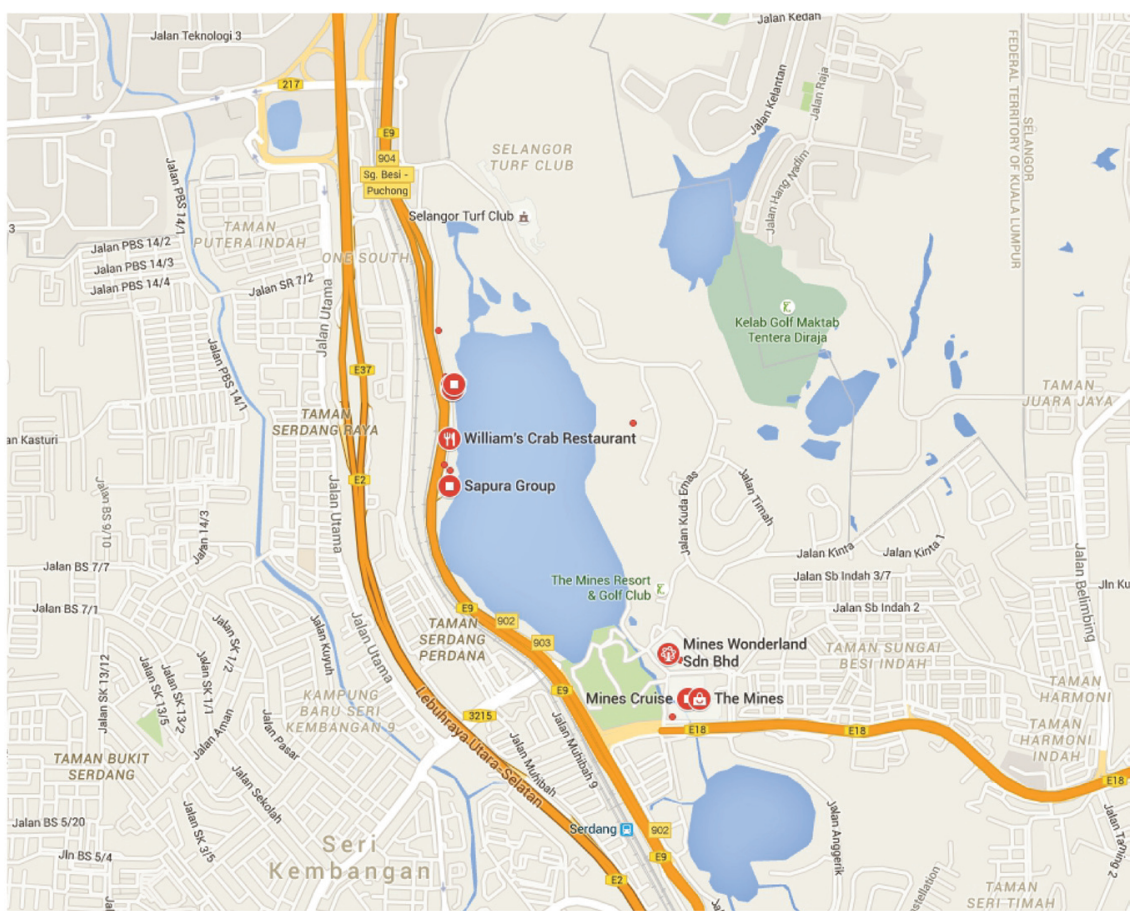

FIGURE 2. Satellite map for Tasik Mines, Seri Kembangan, Malaysia

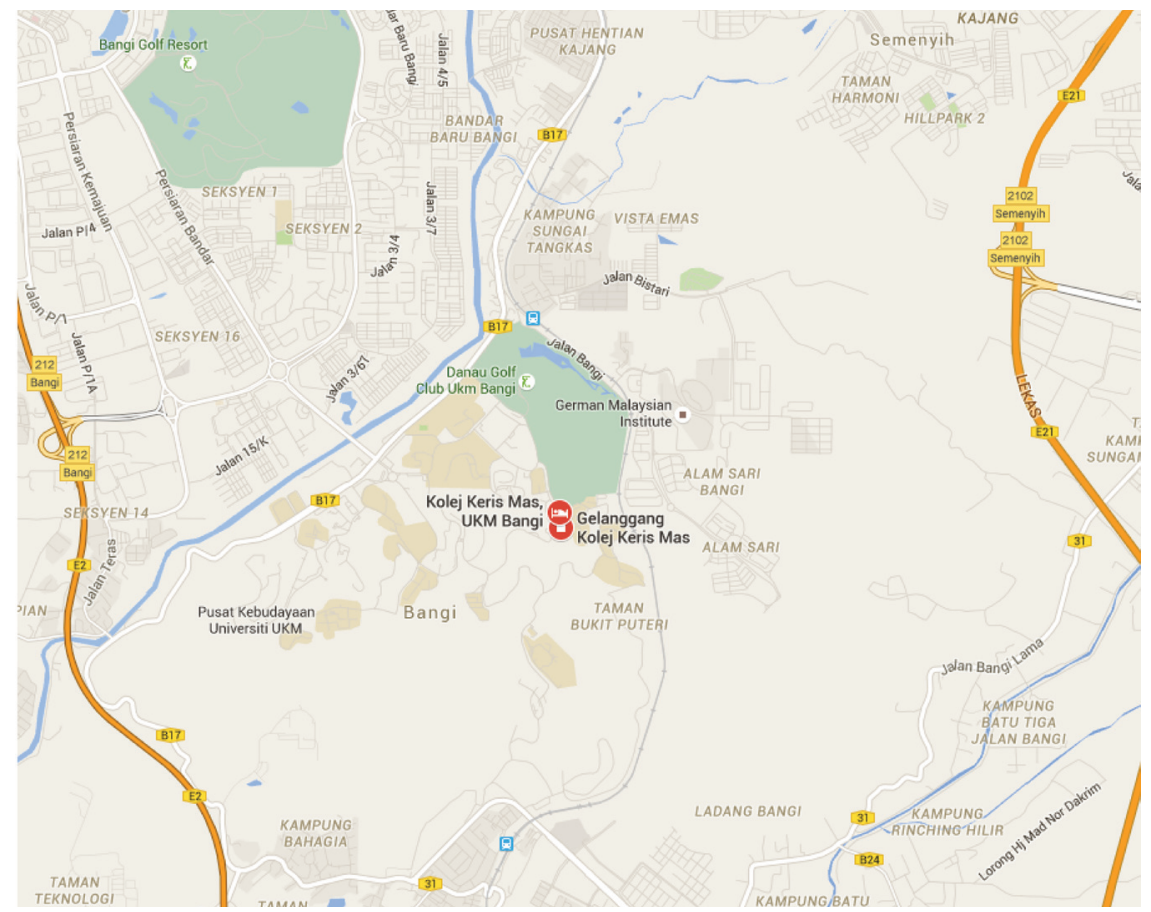

FIGURE 3. Satellite map for tube well, Kolej Keris Mas, Universiti Kebangsaan Malaysia, Bangi, Malaysia

MEMBRANE PERFORMANCE EVALUATION

A laboratory bench-scale dead-end membrane filtration test rig depicted in Figure 4 was used to evaluate the performance of the commercial flat-sheet membranes. The laboratory bench-scale dead-end membrane filtration test rig was equipped with a nitrogen gas tank, a stainless steel stirred cell, a magnetic stirrer, and an electronic balance. The commercial flat sheet membrane was cut into disc shape with an effective membrane filtration area of $19.6 \mathrm{~cm}^{2}$ and placed on the membrane holder inside the stainless steel stirred cell. Following, the feed water was filled into the stainless stirred cell and nitrogen gas was used to exert the operating pressure on the membrane to strat up the filtration process. The operating pressure for NF270 and BW30 membranes were 10 bar and 13 bar, respectively. The magnetic stirrer was operated along the experiment to ensure the homogeneity 
of the feed water inside the stainless steel stirred cell. The treated permeate was collected in a beaker and the weight of the treated permeate was measured using the electronic balance.

The specific pressure-driven permeate water flux (PWF) of the membrane at a constant pressure was determined by direct measurement of permeate volume over the time:

$$
F \frac{7}{A t}
$$

Where $F$ is the PWF $\left(\mathrm{L} / \mathrm{m}^{2} \mathrm{~h}\right), A$ is the effective membrane filtration area $\left(\mathrm{m}^{2}\right), V$ is the permeate volume $(\mathrm{L})$, and $t$ is the filtration time required to collect $V(h)$.

\section{WATER SAMPLE ANALYSIS}

The performance of each commercial flat-sheet membrane in treating the lake water, mine water, and tube well water was evaluated by assessing the permeate water quality based on chemical oxygen demand (COD), ammonia nitrogen $\left(\mathrm{NH}_{3}-\mathrm{N}\right)$, colour, total suspended solid (TSS), $\mathrm{pH}$, and temperature.

$\mathrm{NH}_{3}-\mathrm{N}$ was analysed using Nessler method using the DR 3900 Benchtop Spectrophotometer with RFID* Technology (Hach Company, Colorado, USA) at the wavelength of 425 $\mathrm{nm}$. COD was measured using reactor digestion method by means of a DR 3900 Benchtop Spectrophotometer with RFID* Technology (Hach Company, Colorado, USA) at low range (3-150 $\mathrm{mg} / \mathrm{L})$. Whereas, colour of the water sample was measured based on platinum-cobalt standard method using DR3900 Benchtop spectrophotometer with RFID* Technology (Hach Company, Colorado, USA). TSS of the water sample was measured by weighing the weight of suspended solids (SS) left on $0.45 \mu \mathrm{m}$ diameter cellulose nitrate membrane filter after used to separate the liquid and the SS. $\mathrm{pH}$ of the water sample was measured using the $\mathrm{pH}$ meter (Hanna Instrument, USA).

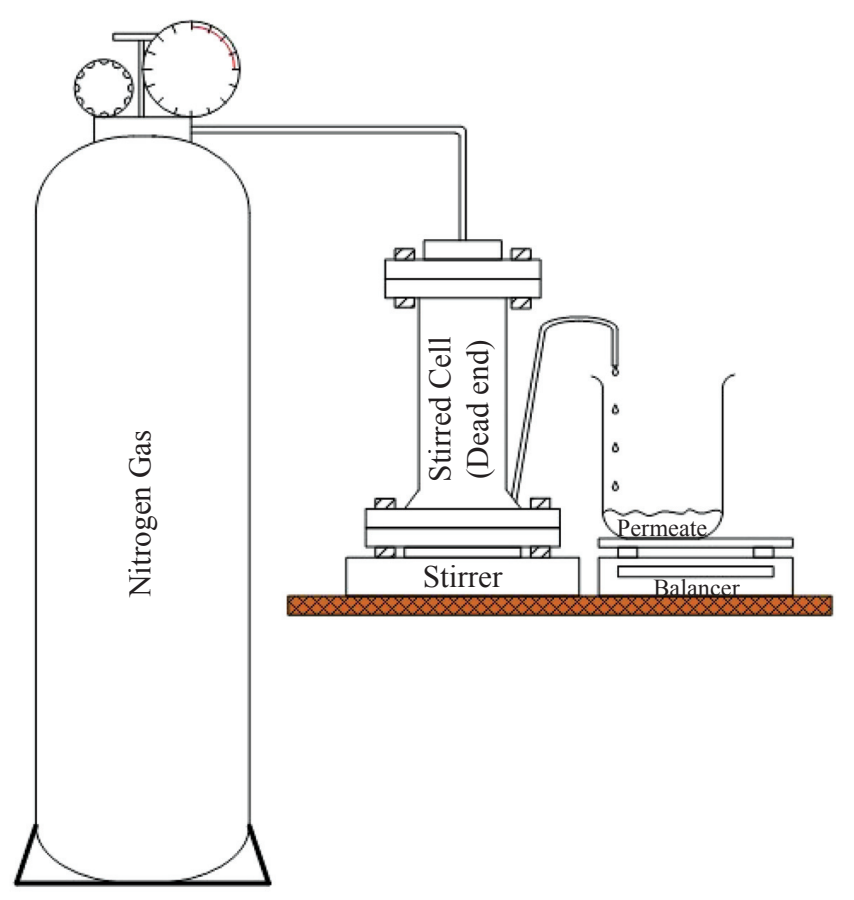

FIGURE 4. Laboratory bench-scale dead-end membrane filtration test rig

\section{RESULTS AND DISCUSSION}

PERMEATE WATER FLUX (PWF)

Figure 5 showed the PWF of NF270 and BW30 membranes in filtering the lake water, mine water, and tube well water at the operating pressure of $10 \mathrm{bar}$ and $13 \mathrm{bar}$, respectively. NF270 membrane showed a higher PWF compared to BW30 membrane regardless the feed water sample. This indicated that the water molecules were permeate faster through the NF270 membrane pores, leading to a greater PWF. This scenario was possibly due to bigger pore size of NF270 membrane (200-400 MWCO) as compared to the BW30 membrane ( $100 \mathrm{MWCO})$ as depicted in Table 1.
On the other hand, NF270 membrane used in filtering the mine water was experienced the most severe fouling phenomenon. The severe fouling phenomenon of NF270 membrane in filtering the mine water was clearly illustrated by the lowest PWF among other feed water sample (tube well water and lake water). The severe fouling attributed by mine water was mainly due to the bad mine water quality which leads to the formation of fouling layer deposited on NF270 membrane surface or into the membrane pores, thus resulting in flux decline (Field 2010; Teow et al. 2017; Teow et al. 2017).

However, BW30 membrane was experiencing the least effect. This phenomena is due to the extremely small average pore size of BW30 membrane, therefore less fouling was 


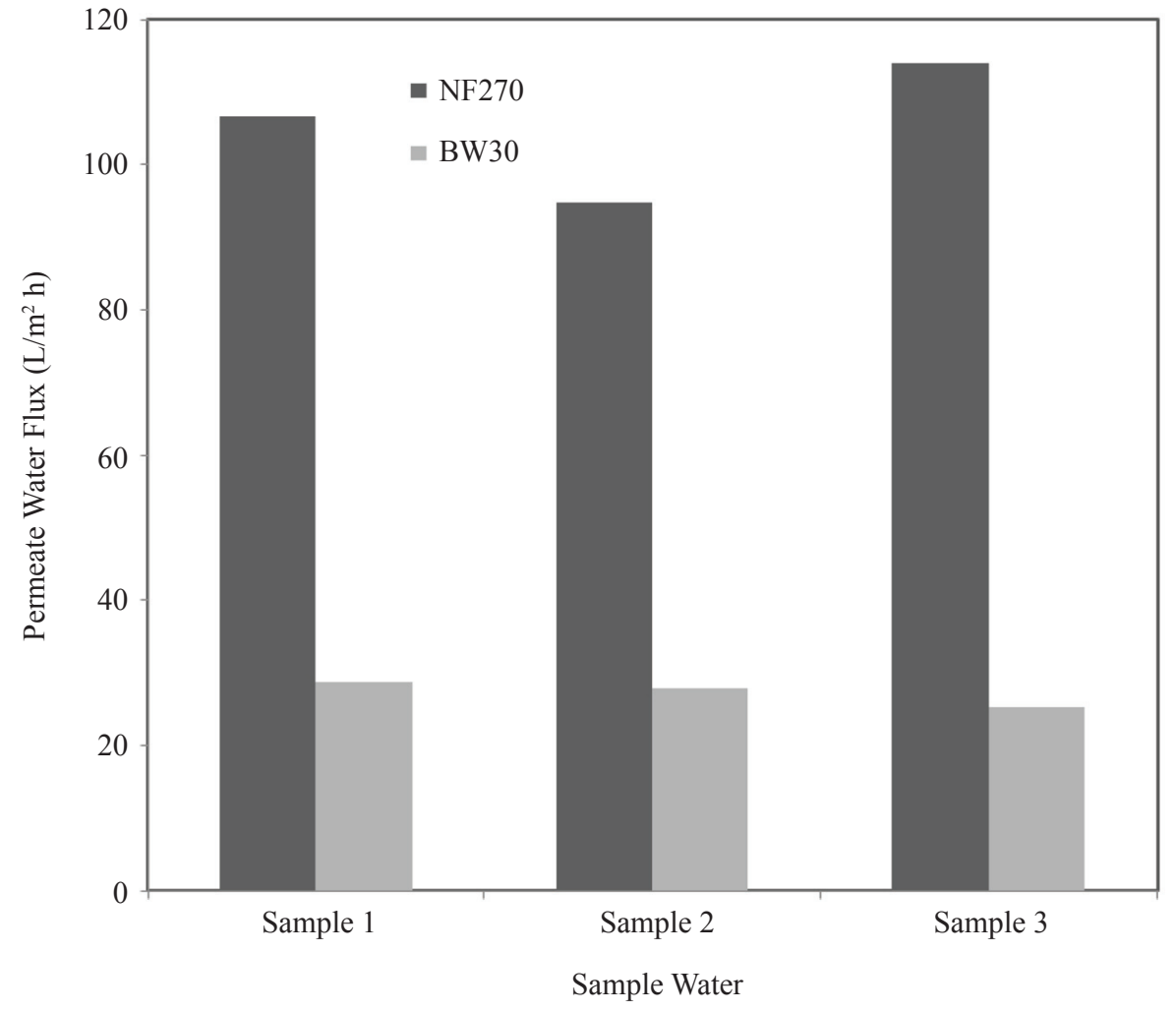

FIGURE 5. Permeate water flux of NF270 and BW30 membranes at 10 bar and 13 bar of operating pressure, respectively

formed on the membrane surface or into the membrane pores. Deposited solute particles on the membrane surface were easily flashed away by the water flux at the feed side.

\section{PERMEATE WATER QUALITY}

Permeate water quality of Sample 1, Sample 2, and Sample 3 after filtering with NF270 and BW30 membranes were characterised by assessing the parameter of COD, colour, $\mathrm{NH}_{3}-\mathrm{N}$, TSS, and temperature. The results were summarised and tabulated in Table 2, Table 3, and Table 4 for Sample 1, Sample 2, and Sample 3, respectively.
As shown in Table 2, Table 3, and Table 4, Sample 2 (mine water) was having the worst feed water quality as compared to the other feed water sample. Membrane filtration process had successfully reduced all analysing parameters. BW30 membrane was depicted a better performance in treating the feed water sample where the analysing paramters of the treated permeated after BW30 membrane filtration process were reduced to a greater extent. This was attributed to the smaller membrane pore size of BW30 membrane which had prohibited the solute particles from permeate through the membrane.

TABLE 2. Characteristics of Sample 1 permeate water under different membrane filtration processes

\begin{tabular}{ccccc}
\hline \multirow{2}{*}{ Parameters } & Unit & \multicolumn{3}{c}{ Sample 1 } \\
\cline { 3 - 5 } & & Feed & NF270 & BW30 \\
\hline COD & $\mathrm{mg} / \mathrm{L}$ & 38.00 & 34.00 & 26.50 \\
Colour & $\mathrm{PtCO}$ & 0.55 & 0.12 & 0.09 \\
$\mathrm{NH}_{3}-\mathrm{N}$ & $\mathrm{mg} / \mathrm{L}$ & 0.32 & 0.29 & 0.15 \\
$\mathrm{TSS}$ & $\mathrm{mg} / \mathrm{L}$ & 0.50 & 0.40 & 0.10 \\
Temperature & ${ }^{\circ} \mathrm{C}$ & 27.70 & 27.90 & 28.10 \\
$\mathrm{pH}$ & - & 7.60 & 6.90 & 7.20 \\
\hline
\end{tabular}


TABLE 3. Characteristics of Sample 2 permeate water under different membrane filtration processes

\begin{tabular}{ccccc}
\hline \multirow{2}{*}{ Parameters } & Unit & \multicolumn{3}{c}{ Sample 1 } \\
\cline { 3 - 5 } & & Feed & NF270 & BW30 \\
\hline COD & $\mathrm{mg} / \mathrm{L}$ & 43.50 & 38.50 & 26.90 \\
Colour & $\mathrm{PtCO}$ & 67.67 & 16.00 & 11.00 \\
$\mathrm{NH}_{3}-\mathrm{N}$ & $\mathrm{mg} / \mathrm{L}$ & 0.65 & 0.29 & 0.15 \\
$\mathrm{TSS}$ & $\mathrm{mg} / \mathrm{L}$ & 1.10 & 0.40 & 0.00 \\
Temperature & ${ }^{\circ} \mathrm{C}$ & 25.50 & 27.00 & 27.30 \\
$\mathrm{pH}$ & - & 7.50 & 6.90 & 7.50 \\
\hline
\end{tabular}

TABLE 4. Characteristics of Sample 3 permeate water under different membrane filtration processes

\begin{tabular}{ccccc}
\hline \multirow{2}{*}{ Parameters } & Unit & \multicolumn{3}{c}{ Sample 1 } \\
\cline { 3 - 5 } & & Feed & NF270 & BW30 \\
\hline $\mathrm{COD}$ & $\mathrm{mg} / \mathrm{L}$ & 32.60 & 29.50 & 26.20 \\
Colour & $\mathrm{PtCO}$ & 27.00 & 21.00 & 9.30 \\
$\mathrm{NH}_{3}-\mathrm{N}$ & $\mathrm{mg} / \mathrm{L}$ & 0.50 & 0.31 & 0.29 \\
$\mathrm{TSS}$ & $\mathrm{mg} / \mathrm{L}$ & 0.40 & 0.20 & 0.00 \\
Temperature & ${ }^{\circ} \mathrm{C}$ & 26.90 & 25.60 & 25.40 \\
$\mathrm{pH}$ & - & 8.30 & 8.30 & 8.30 \\
\hline
\end{tabular}

COMPARISON OF PERMEATE WATER QAULITY WITH NATIONAL WATER QUALITY STANDARD (NWQS)

In order to prove the reuse concept of the membrane technology, the treated permeate water quality after the membrane filtration processes was tabulated and compared with NWQS of Malaysia. NWQS is the standard for potable water usage such as drinking, cooking, and agriculture.
Comparison of treated permeate water quality after the membrane filtration processes in Table 5, Table 6, and Table 7 shown that the treated permeate water was unable to meet the Class I NWQS due to the higher COD concentration. However, the treated permeate water were able to comply the Class III NWQS, which was suitable to be recycled for livestock drinking and irrigation purposes (Zainudin 2010).

TABLE 5. Comparison of Sample 1 permeate water with NWQS

\begin{tabular}{|c|c|c|c|c|c|c|c|}
\hline \multirow{2}{*}{ Parameter } & \multirow{2}{*}{ NF270 } & \multirow{2}{*}{ BW30 } & \multicolumn{5}{|c|}{ National Water Quality Standard } \\
\hline & & & I & II & III & IV & V \\
\hline $\mathrm{COD}(\mathrm{mg} / \mathrm{L})$ & 34.00 & 26.50 & $<10$ & $10-25$ & $25-50$ & $50-100$ & $>100$ \\
\hline Colour (PtCO) & 0.12 & 0.09 & 15 & 150 & 150 & - & - \\
\hline $\mathrm{NH}_{3}-\mathrm{N}(\mathrm{mg} / \mathrm{L})$ & 0.29 & 0.15 & $<0.1$ & $0.1-0.3$ & $0.3-0.9$ & $0.9-2.7$ & $>2.7$ \\
\hline TSS (mg/L) & 0.40 & 0.10 & $<25$ & $25-50$ & $50-150$ & $150-300$ & $>300$ \\
\hline Temperature $\left({ }^{\circ} \mathrm{C}\right)$ & 27.90 & 28.10 & - & - & - & - & - \\
\hline $\mathrm{pH}$ & 6.90 & 7.20 & $>7$ & $6-7$ & $5-6$ & $<5$ & $>5$ \\
\hline \multirow{2}{*}{ Parameter } & \multirow{2}{*}{ NF270 } & \multirow{2}{*}{ BW30 } & \multicolumn{5}{|c|}{ National Water Quality Standard } \\
\hline & & & I & II & III & IV & V \\
\hline $\mathrm{COD}(\mathrm{mg} / \mathrm{L})$ & 38.50 & 26.90 & $<10$ & $10-25$ & $25-50$ & $50-100$ & $>100$ \\
\hline Colour (PtCO) & 16.00 & 11.00 & 15 & 150 & 150 & - & - \\
\hline $\mathrm{NH}_{3}-\mathrm{N}(\mathrm{mg} / \mathrm{L})$ & 0.29 & 0.15 & $<0.1$ & $0.1-0.3$ & $0.3-0.9$ & $0.9-2.7$ & $>2.7$ \\
\hline TSS (mg/L) & 0.40 & 0.00 & $<25$ & $25-50$ & $50-150$ & $150-300$ & $>300$ \\
\hline Temperature $\left({ }^{\circ} \mathrm{C}\right)$ & 27.00 & 27.30 & - & - & - & - & - \\
\hline $\mathrm{pH}$ & 6.90 & 7.50 & $>7$ & $6-7$ & $5-6$ & $<5$ & $>5$ \\
\hline
\end{tabular}


TABLE 7. Comparison of Sample 3 permeate water with NWQS

\begin{tabular}{|c|c|c|c|c|c|c|c|}
\hline \multirow{2}{*}{ Parameter } & \multirow{2}{*}{ NF270 } & \multirow{2}{*}{ BW30 } & \multicolumn{5}{|c|}{ National Water Quality Standard } \\
\hline & & & I & II & III & IV & $\mathrm{V}$ \\
\hline $\mathrm{COD}(\mathrm{mg} / \mathrm{L})$ & 29.50 & 26.20 & $<10$ & $10-25$ & $25-50$ & $50-100$ & $>100$ \\
\hline Colour $(\mathrm{PtCO})$ & 21.00 & 9.30 & 15 & 150 & 150 & - & - \\
\hline $\mathrm{NH}_{3}-\mathrm{N}(\mathrm{mg} / \mathrm{L})$ & 0.31 & 0.29 & $<0.1$ & $0.1-0.3$ & $0.3-0.9$ & $0.9-2.7$ & $>2.7$ \\
\hline TSS (mg/L) & 0.20 & 0.00 & $<25$ & $25-50$ & $50-150$ & $150-300$ & $>300$ \\
\hline Temperature $\left({ }^{\circ} \mathrm{C}\right)$ & 25.60 & 25.40 & - & - & - & - & - \\
\hline $\mathrm{pH}$ & 8.30 & 8.30 & $>7$ & $6-7$ & $5-6$ & $<5$ & $>5$ \\
\hline
\end{tabular}

CONCLUSION

In conclusion, membrane technology showed the potential for the treatment of lake water, mine water, and tube well water in enhancing the water quality with the removal of COD, colour, $\mathrm{NH}_{3}-\mathrm{N}$, and TSS. Different membrane module was having different extent of removal efficiency, basically depended on the rejection capability of the membrane which predominantly attributed by the membrane morphology. Permeate water filtered by NF270 and BW30 membranes were able to meet the Class III NWQS, eventually leading to recycle for livestock drinking and irrigation purposes.

\section{ACKNOWLEDGEMENT}

The author wish to gratefully acknowledge the financial support for this work by Geran Universiti Penyelidikan (GUP-2017-098) and Dana Penyelidikan Strategik (KRA2017-016).

REFERENCES

Asian Development Bank. 2016. El Nino, poor water management, and climate change bringing droughts to Asia and the pacific. https://www.adb.org/news/features/ el-nino-poor-water-management-and-climate-changebringing-droughts-asia-and-pacific [5 November 2017]

EEA. 2012. Water stress. http://www.eea.europa.eu/themes/ water/wise-help-centre/glossary-definitions/water-stress [2 April 2016]

Field, R. 2010. Fundamentals of fouling in membrane technology: Membranes for water treatment. WileyVCH Verlag GmbH \& Co.

Hodgson, J. 2016. Freshwater crisis, national geographic. http:// environment.nationalgeographic.com/environment/ freshwater/freshwater-crisis [2 April 2016]

Rana, D., Matsuura, T., Narbaitz, R.M. \& Feng, C. 2005. Development and characterization of novel hydrophilic surface modifying macromolecule for polymeric membranes. Journal of Membrane Science 249: 103-112.

Tarrass, F. \& Benjelloun, M. 2012. The effects of water shortages on health and human development. Perspective in Public Health 132(5): 240-244.

Teow, Y.H., Ooi, B.S. \& Ahmad, A.L. 2017. Fouling behaviour of PVDF-TiO 2 mixed-matrix membrane applied to humic acid treatment. Journal of Water Process Engineering 15: 89-98.
Teow, Y.H., Ooi, B.S. \& Ahmad, A.L. 2017. Study on PVDF$\mathrm{TiO}$ mixed-matrix membrane behaviour towards humic acid adsorption. Journal of Water Process Engineering 15: 99-106.

The Water Project Organization. 2014. Facts about water: Statistics of the water crisis. http://thewaterproject.org/ water_stats [2 April 2016]

UN Water Organization. 2013. Facts and figures. http://www. unwater.org/water-cooperation-2013/water-cooperation/ facts-and-figures/en/ [3 April 2016]

World Vision. 2016. El Nino causing catastrophic water shortages across the world, affecting children the most says World Vision. https://reliefweb.int/report/world/ el-nino-causing-catastrophic-water-shortages-acrossworld-affecting-children-most-says [5 November 2017]

Zaiedy, N.I., Karim, O.A. \& Mutalib, N.A.A. 2016. Water quality of surface runoff in loop two catchment area in UKM. Jurnal Kejuruteraan 28: 65-72.

Zainudin, E.Z. 2010. Benchmarking river water quality in Malaysia. Jurutera February: 12-15.

*Teow Yeit Haan

Research Centre for Sustainable Process Technology

(CESPRO)

Faculty of Engineering and Built Environment

Universiti Kebangsaan Malaysia

43600 Bangi

Selangor, Malaysia.

Mohd Syahmi Hafizi Bin Ghani

Wan Nur Athirah Binti Wan Mohammad Hamdan

Nurul 'Adilah Binti Rosnan

Noorini Izzati Binti Mohamad Mazuki

Ho Kah Chun

Chemical Engineering Program

Faculty of Engineering and Built Environment

Universiti Kebangsaan Malaysia

43600 Bangi

Selangor, Malaysia.

*Corresponding author; email: yh_teow@ukm.edu.my

Received date: $25^{\text {th }}$ May 2017

Accepted date: $14^{\text {th }}$ September 2017

In Press date: $15^{\text {th }}$ December 2017

Published date: $31^{\text {st }}$ December 2017 
